\title{
クヌギ精英樹 $\mathbf{F}_{1}$ 実生採種園の家系内選抜により実現された 初期成長の改良効果
}

\author{
山田浩雄 ${ }^{*, 1} \cdot$ 久保田正裕 ${ }^{2} \cdot$ 磯田圭哉 $^{2}$
}

\begin{abstract}
クヌギ精英樹 $\mathrm{F}_{1}$ 実生採種園の家系内選抜によって得られる改良効果の期待值と実現值について検討した。 $\mathrm{F}_{1}$ 実生採種園は, クヌギ精英樹の自然交配 $\mathrm{F}_{1}$ 実生苗 22 家系を用いて造成され，4 年次の樹高成長による $50 \%$ の家系内選抜によって, $3.4 \%$ の改 良効果が期待された。 $\mathrm{F}_{2}$ 実生採種園は, 自然交配の $\mathrm{F}_{2}$ 実生苗 6 家系に改良効果を確認するための対照用 $\mathrm{F}_{1}$ 実生苗 6 家系を加 えて造成され，5年次の樹高成長を比較した結果， $4.0 \%$ の改良効果が確認された。改良効果の期待值と実現值は良く一致し， $\mathrm{F}_{2}$ 実生家系集団の平均樹高は $\mathrm{F}_{1}$ 実生集団の平均樹高よりも有意に大きかった。クヌギの育種を行う上で, 実生採種園の家系内 選抜による改良方法が有効であることが確認された。

キーワード：実現された遺伝獲得量，家系内選抜，クヌギ，実生採種園，精英樹
\end{abstract}

\begin{abstract}
Hiroo Yamada, ${ }^{*}, 1$ Masahiro Kubota, ${ }^{2}$ Keiya Isoda ${ }^{2}$ (2011) Realized Genetic Gain of Initial Height Growth Caused by Within-family Selection of the $F_{1}$ Seedling Seed Orchard for Kunugi (Quercus acutissima) Plus Trees. J Jpn For Soc 93: 139-142 Realized genetic gains of initial height growth caused by within-family selection of the $F_{1}$ seedling seed orchard for Kunugi (Quercus acutissima) plus trees were compared with predicted ones. Predicted genetic gains for $50 \%$ within-family selection of the $\mathrm{F}_{1}$ seedling seed orchard were a $3.4 \%$ increase in height growth based on 4-year height growth data. This $\mathrm{F}_{1}$ seedling seed orchard consisted of 22 open-pollinated families. Realized genetic gains, which were $4.0 \%$ in height growth, were evaluated by analyzing 5 -year height growth data collected from the $\mathrm{F}_{2}$ seedling seed orchard. This $\mathrm{F}_{2}$ seedling seed orchard comprised 6 open-pollinated $\mathrm{F}_{2}$ families and 6 open-pollinated $\mathrm{F}_{1}$ families. The realized genetic gains were comparable to the predicted ones. The mean height of the $\mathrm{F}_{2}$ family population outperformed that of the $F_{1}$ family population, and the gains were statistically significant. The results of this study confirmed the efficiency of the seedling seed orchard procedure for Kunugi plus trees.
\end{abstract}

Key words: plus tree, Quercus acutissima, realized genetic gains, seedling seed orchard, within-family selection

\section{I. は じめ に}

林木などの他殖性植物の集団を改良するには, 選抜, 交 配, 検定を繰り返す循環選抜育種法によって希望遺伝子の 集積を行っていく（神戸 2005）。林木の成長量を向上させ ることを育種目標とする場合, 伐採・収穫時の表現型によっ て選抜を繰り返さなければならないが，スギやヒノキなど の成長には長い年月が必要なため, 1 回の選抜ごとに選抜 個体によるクローン採種園を造成して, 少しでも改良され た造林用種苗を供給しながら，そのクローン採種園を利用 して交配を行い，次代検定と次世代の選抜が繰り返される (大庭・勝田 1991)。クローン採種園による循環選抜育種 の方法は，選抜された個体のクローン化を行う必要がある ため, クローン増殖が困難なブナ科などの有用広葉樹の育 種では，そのクローン増殖が大きなネックとなっている。

クローン増殖が困難な樹種では, 実生採種園による方法 が有効で, アカシアマンギューム等の熱帯早生樹種では, 実生採種園による循環選抜育種が行われている（Kurinobu 1999; Nirsatmanto and Kurinobu 2002; Nirsatmanto et al. 2004; Leksono et al. 2008)。実生採種園では，選抜した個
体から種子を採取し，その実生苗を用いて次代検定を兼ね て採種園を造成する。その後, 実生採種園で家系選抜や家 系内選抜により不良木を間伐淘汰させて, 次世代の優良木 だけを残した後で種子生産を行うとともに, 次世代の実生 採種園の造成を行い, これらの作業を繰り返す (Kurinobu 1999）。このような実生採種園による方法は，これまで日 本の林木育種ではほとんど行われてこなかった。

クヌギ（Quercus acutissima Carruth.）は東北地方以南 の暖温带に広く分布し, 里山を代表する有用広葉樹の一つ である。春に開花して翌年の秋に結実する（大場 1989）。 古くからしいたけ原木や薪炭材などとして利用され, 造林 用種苗の生産が行われている。林木育種の分野では, 1979 年から「しいたけ原木育種事業」が実施され, 多くの精英 樹が選抜されてきた（大庭・勝田 1991）。これら精英樹の 自然交配実生苗を用いて造林した場合，未選抜の実生苗と 比べて, 樹高成長で $37 \%$ の精英樹選抜の効果があったと 報告されている（山田・久保田 2009）。しかしながら，ク ヌギはクローン増殖が比較的困難な樹種であり, その原因 であるつぎ木台木と穂木との間に生じる不親和性の問題が 解決していないため, クローン採種園産種子による次代検

\footnotetext{
*連絡先著者（Corresponding author） E-mail : hirooy@affrc.go.jp

1 独立行政法人森林総合研究所林木育種センター九州育種場 ㅎ 861-1102 合志市須屋 2320-5 (Kyushu Regional Breeding Office, Forest Tree Breeding Center, Forestry and Forest Products Research Institute, 2320-5 Suya, Koshi 861-1102, Japan)

${ }^{2}$ 独立行政法人森林総合研究所林木育種センター関西育種場 709-4335 岡山県勝田郡勝央町植月中 1043 (Kansai Regional Breeding Office, Forest Tree Breeding Center, Forestry and Forest Products Research Institute, 1043 Uetsuki-naka, Shoo, Katsuta-gun, Okayama 709-4335, Japan)

（2010 年 9 月 13 日受付; 2011 年 4 月 14 日受理）
} 
定と次世代の選抜が滞っている（大庭・勝田 1991）。この ような樹種では，実生採種園による循環選抜育種の方法が 有効と考えられる。

本研究の目的は, クローン増殖が困難な樹種について, これまで日本の林木育種では行われてこなかった実生採種 園による循環選抜育種の可能性を検討するために, クヌギ 精英樹の自然交配種子（ $\mathrm{F}_{1}$ ) による実生採種園を造成して 家系内選抜を行い, その実現された改良効果を次世代 $\left(\mathrm{F}_{2}\right)$ で確認することである。今回は，実現された改良効果を比 較的短期間に求めることができる初期成長の改良に着目し て，(1）クヌギ精英樹の $\mathrm{F}_{1}$ 実生採種園における樹高成長 の遺伝率と家系内選抜を行った選抜差から，次世代 $\left(\mathrm{F}_{2}\right)$ に期待される遺伝獲得量を推定し，（2） $\mathrm{F}_{1}$ 実生採種園か ら家系内選抜後の自然交配種子 $\left(\mathrm{F}_{2}\right)$ を採取して $\mathrm{F}_{2}$ 実生 採種園を造成し，実現された遺伝獲得量を求めた。

\section{II. 材 料 と 方 法}

\section{1. $\mathbf{F}_{1}$ 実生採種園}

（独）森林総合研究所林木育種センター関西育種場四国 増殖保存園内（高知県香美市）に 1981 年 3 月に設定した クヌギ精英樹クローン集植所（P）において，結実量の多 かったクローンの異なる 22 母樹（ラメート）から，1994 年 10 月に自然交配種子 $\left(\mathrm{F}_{1}\right)$ を採取した。このクローン 集植所には，徳島県と愛媛県で選抜されたクヌギ精英樹 51 個体のつぎ木クローンが各 1 5 ラメートで列状植栽さ れていて，毎年，半数程度のクローンで開花結実が観察 される集植所であった。なお，種子を採取した 22 クロー ン以外のクローンやラメートでは，結実していないか，ま たは，結実量が少なかった。1995 年 4 月に同保存園内の 苗畑に播種し，播種後 1 成長期経過した 1996 年 3 月に, 2 回反復の乱塊法（1家系あたり $4 \sim 9$ 個体 $\times 2$ 反復，計 258 本）で $\mathrm{F}_{1}$ 実生採種園を同保存園内に設定した。播種後 4 成長期が経過した 1998年11月に樹高を調査して,そのデー 夕に基づき， 22 家系 2 反復の 44 プロットそれぞれについ て，樹高成長の優れた 2〜4 個体を残して間伐する $50 \%$ のプロット内選抜（家系内選抜）を 1999 年 6 月に行った (Nirsatmanto and Kurinobu 2002)。

\section{2. $\mathbf{F}_{2}$ 実生採種園}

$\mathrm{F}_{1}$ 実生採種園を構成する 22 家系の中で，プロット内選 抜後の 2000 年春に開花して結実のみられた家系の異なる 6 母樹から, 2001 年 10 月に自然交配種子 $\left(\mathrm{F}_{2}\right)$ を採取した。 なお，他の 16 家系では結実していなかった。この $\mathrm{F}_{1}$ 実生 採種園産 $\mathrm{F}_{2}$ 種子と同じ母樹系統の $\mathrm{F}_{1}$ 種子を，クヌギ精英 樹クローン集植所（P）の 6 母樹から同時に採取し，実現 された遺伝獲得量を求めるための対照とした。これら 12 母樹から採取した自然交配種子 $\left(\mathrm{F}_{1}\right.$ と $\left.\mathrm{F}_{2}\right)$ を，2002 年 4 月に四国増殖保存園内の苗畑に播種し，播種後 1 成長期経 過した 2002 年 10 月に，単木混交（1家系あたり 5 20 個 体，計 200 本）で $\mathrm{F}_{2}$ 実生採種園（ $\mathrm{F}_{1}$ 家系集団と $\mathrm{F}_{2}$ 家系集 団の比較試験地）を同保存園内に設定した。播種後 5 成長
期経過した 2007 年 1 月に樹高を調査し， $\mathrm{F}_{1}$ 家系集団と $\mathrm{F}_{2}$ 家系集団の平均樹高を比較して実現された遺伝獲得量を求 めた。

\section{3. 統 計解 析}

$\mathrm{F}_{1}$ 実生採種園でのプロット内選抜による遺伝獲得量を 推定するため，播種後 4 成長期後の樹高デー夕を用いて, 下式の線型モデルを仮定した分散分析を行い，分散成分を 推定した（栗延 2007）。

$$
y_{i j k}=\mu+\alpha_{i}+\beta_{j}+\alpha \beta_{i j}+\varepsilon_{i j k}
$$

ここで, $y_{i j k}$ は $i$ 番目のブロックの $j$ 番目の家系の $k$ 番目 の個体の樹高, $\mu$ は全個体の平均值， $\alpha_{i}$ は $i$ 番目のブロッ クの効果, $\beta_{j}$ は $j$ 番目の家系の効果, $\alpha \beta_{i j}$ は $i$ 番目のブロッ クと $j$ 番目の家系の交互作用， $\varepsilon_{i j k}$ は誤差である。また, プロット内選抜による遺伝獲得量の期待值は下式により推 定した（Namkoong et al. 1988 ; 栗延 2007)。

$$
G=S_{w} \times h_{w}{ }^{2}=i_{w} \times \delta_{w} \times \frac{(3 / 4) \delta_{A}{ }^{2}}{\delta_{w}{ }^{2}}
$$

ここで， $G$ は遺伝獲得量の期待值， $S_{w}$ はプロット内選 抜差, $h_{w}{ }^{2}$ は家系の遺伝率， $i_{w}$ はプロット内選抜強度， $\delta_{w}$ はプロット内変異の標準偏差, $\delta_{A}{ }^{2}$ は相加的遺伝分散 $(4$ ×家系分散）である。プロット内選抜強度 $\left(i_{w}\right)$ は, プロッ トごとに求めた選抜強度の平均值とした。

$\mathrm{F}_{2}$ 実生採種園（ $\mathrm{F}_{1}$ 家系集団と $\mathrm{F}_{2}$ 家系集団の比較試験地） での実現された改良効果を確認するため，播種後 5 成長期 後の樹高デー夕を用いて，下式の線型モデルを仮定した分 散分析を行った。

$$
y_{i j k}=\mu+\gamma_{i}+\beta(\gamma)_{i j}+\varepsilon_{i j k}
$$

ここで， $y_{i j k}$ は $i$ 番目の家系集団の $j$ 番目の家系の $k$ 番目の 個体の樹高, $\gamma_{i}$ は $i$ 番目の家系集団の効果, $\beta(\gamma)_{i j}$ は $i$ 番目 の家系集団内の $j$ 番目の家系の効果， $\varepsilon_{i j k}$ は誤差である。

以上の分散分析と分散成分の推定はSPSS 12.0J for Windows を用いて計算した。

\section{III. 結果}

\section{1. $F_{1}$ 実生採種園}

$\mathrm{F}_{1}$ 実生採種園の播種後 4 成長期経過時点における各家 系の平均樹高は, $2.74 \sim 3.79 \mathrm{~m}$ の範囲にあり, 全体の平均 值（プロット内選抜前の平均樹高， 22 家系 255 個体）は $3.34 \mathrm{~m}$ であった。（1）式による分散分析の結果，ブロック 間差，家系間差，ブロックと家系の交互作用は全て統計的 に有意であった（表-1）。各プロットについて，樹高成長 の優れた半数の個体 (2〜 4 個体) を選抜した結果, 各プロッ 卜の選抜差は 0.04 0.68 m の範囲にあり，プロット内選 抜差 $\left(S_{w}\right)$ は，プロット内選抜強度 $\left(i_{w}=0.707\right)$ とプロッ 卜内変異の標準偏差 $\left(\delta_{w}=0.502\right)$ の積により $0.36 \mathrm{~m}$ と計 算された（図-1）。家系の遺伝率 $\left(h_{w}{ }^{2}\right)$ は 0.321 と計算さ れ $\left(\delta_{A}{ }^{2}=0.108\right)$, プロット内選抜による遺伝獲得量の期待 值（G）は，(2) 式により $0.11 \mathrm{~m}$ と計算された。これは今 
表-1. $F_{1}$ 実生採種園における樹高（播種後 4 成長期後）の分 散分析表

\begin{tabular}{crcc}
\hline 要 & 因 & 自由度 & 平均平方 \\
\hline 反復 & 1 & 2.903 & $* * *$ \\
家系 & 21 & 0.728 & $* * *$ \\
反復 $\times$ 家系 & 21 & 0.442 & $*$ \\
誤差 & 211 & 0.252 & \\
\hline
\end{tabular}

***, $0.1 \% ; *$ * $5 \%$ の危険率で有意差あり。

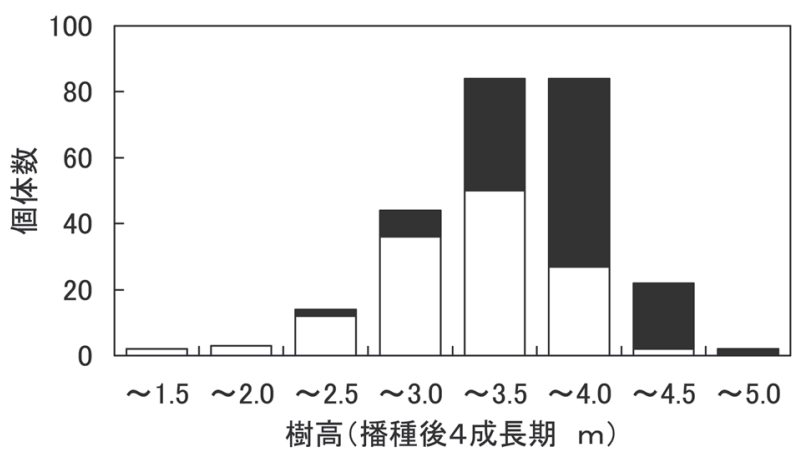

図-1， $\mathrm{F}_{1}$ 実生採種園における樹高階別の頻度分布図 口は間伐個体，口は選抜個体を示す。

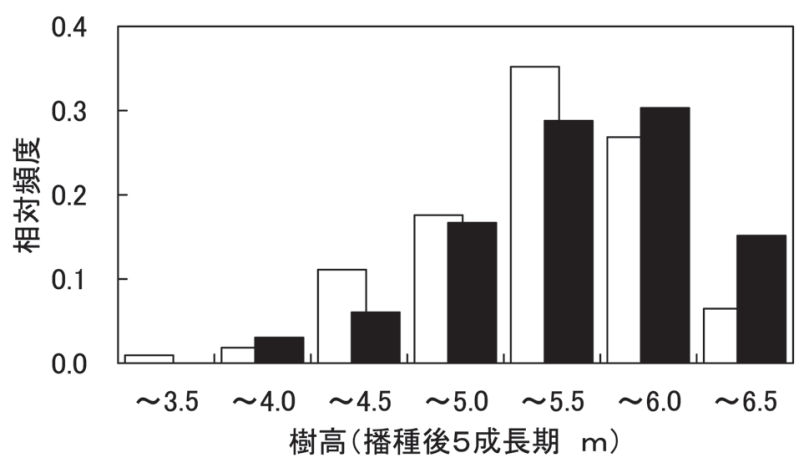

図-2. $\mathrm{F}_{2}$ 実生採種園における樹高階別の頻度分布図 $\square$ 品 個体 (改良効果の比較用),

は $\mathrm{F}_{2}$ 個体を示す。

回の $\mathrm{F}_{1}$ 実生採種園のプロット内選抜により，樹高成長に ついて $3.4 \%$ の改良効果が期待できることを示している。

\section{2. $\mathbf{F}_{2}$ 実生採種園}

$\mathrm{F}_{2}$ 実生採種園 $\left(\mathrm{F}_{1}\right.$ 家系集団と $\mathrm{F}_{2}$ 家系集団の比較試験地) の播種後 5 成長期経過時点における各家系の平均樹高は, $\mathrm{F}_{1}$ 家系が 5.12〜5.36 m， $\mathrm{F}_{2}$ 家系が5.22〜 $5.83 \mathrm{~m}$ の範囲に あった。また， $\mathrm{F}_{1}$ 家系集団（6 家系 108 個体）全体の平均 樹高は $5.25 \mathrm{~m}$ であったのに対し， $\mathrm{F}_{2}$ 家系集団（6 家系 66 個体）全体の平均樹高は $5.46 \mathrm{~m}$ であった（図-2)。（3）式 による分散分析の結果，家系間差は有意ではなかったが， $\mathrm{F}_{1}$ 家系集団と $\mathrm{F}_{2}$ 家系集団の集団間差は有意であり,プロッ 卜内選抜（家系内選抜）の効果が認められた（表-2）。 $\mathrm{F}_{1}$ 家系集団と $\mathrm{F}_{2}$ 家系集団の樹高成長の差（実現された遺伝 獲得量）は $0.21 \mathrm{~m}$ で，改良効果は $4.0 \%$ と計算された。

今回, $\mathrm{F}_{2}$ 実生採種園に供試することのできた $\mathrm{F}_{2} 6$ 家系 について，採種した母樹家系の $\mathrm{F}_{1}$ 実生採種園における間 伐前の平均樹高（播種後 4 成長期経過後）と $\mathrm{F}_{2}$ 実生採種
表-2. $\mathrm{F}_{2}$ 実生採種園における樹高（播種後 5 成長期後）の分 散分析表

\begin{tabular}{lccc}
\hline 要 因 & 自由度 & 平均平方 & \\
\hline 実生世代 & 1 & 1.553 & $*$ \\
家系 & 10 & 0.381 & n.s. \\
誤差 & 162 & 0.383 & \\
\hline
\end{tabular}

*，5\%の危険率で有意差あり；ns，有意差なし。

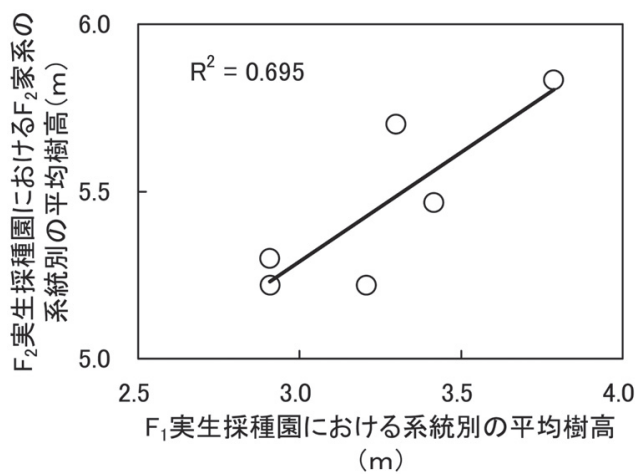

図-3. $\mathrm{F}_{1}$ 実生採種園での樹高成長（間伐前）と $\mathrm{F}_{2}$ 実生 採種園での樹高成長との関係

園での平均樹高（播種後 5 成長期経過後）の関係を図 -3 に示す。 $\mathrm{F}_{1}$ 実生採種園での平均樹高と $\mathrm{F}_{2}$ 実生採種園での 平均樹高との間には有意な正の相関関係が認められ $(p<$ 0.05), $\mathrm{F}_{1}$ 実生採種園で樹高成長が優れていた家系ほど, その $\mathrm{F}_{2}$ 家系の樹高成長は優れていた。

\section{IV. 考察}

本研究における $\mathrm{F}_{1}$ 実生採種園での初期成長に着目した 改良効果の期待值と $\mathrm{F}_{2}$ 実生採種園での実現值は, 調查し た成長期間に 1 年の違いがあるものの，両者でかなり良 い一致を示した。今回の $\mathrm{F}_{1}$ 実生採種園での樹高成長によ る $50 \%$ のプロット内選抜（家系内選抜）によって, 期待 された次世代での改良効果は $3.4 \%$ (図-1), $\mathrm{F}_{2}$ 実生採種 園で害際に確認された改良効果は $4.0 \%$ あり（図-2），プ ロット内選抜による改良効果が確認できた。実生採種園 での改良効果は, (2) 式が示すように, 選抜差や遺伝率に よって変動するので, これら条件の異なる他樹種の報告 と直接比較することはできないが，今回の $50 \%$ のプロッ 卜内選抜による $4.0 \%$ の改良効果は, ユーカリペリ夕の実 生採種園で報告されている 15.6 21.2\%の改良効果よりも 低く (Leksono et al. 2008), アカシアマンギュームで報告 されている 1.7〜 3.9\%の改良効果やジャックパインで報 告されている 1.5 5.3\%の改良効果と同等程度であった (Nirsatmanto et al. 2004; Weng et al. 2008)。さらに強度の プロット内選抜を行うことによる選抜差の増大によって, 改良効果の向上が期待される。

今回の $\mathrm{F}_{1}$ 実生採種園の樹齢は未だ若く，プロット内選 抜後に着果した個体が限られていたことから， $\mathrm{F}_{2}$ 実生採 種園に供試することのできた家系数は少なく，また，自然 交配種子を採取していることから花粉親も不明である。こ 
のことは，特異的な母樹や花粉親が寄与するなど，プロッ 卜内選抜以外の効果が， $\mathrm{F}_{2}$ 実生採種園で確認された遺伝 獲得量に影響している可能性がある（図-2）。今回得られ た改良効果の期待值と実現值は良く一致はしたが， $\mathrm{F}_{1}$ 実 生採種園のさらに多くの個体から種子を採取して，実現さ れた遺伝獲得量を調査することが必要であろう。また，ク ヌギの樹高成長については，播種後 5 成長期未満の樹高と 播種後 10 成長期以上の樹高との幼老相関は低かったこと が報告されている（山田・久保田 2009）。本研究では，プ ロット内選抜による改良効果を確認するため，比較的短期 間に結果の得られる初期成長に着目したが，今回のプロッ 卜内選抜の収穫時における改良効果を確認するためには, $\mathrm{F}_{2}$ 実生採種園（ $\mathrm{F}_{1}$ 家系集団と $\mathrm{F}_{2}$ 家系集団の比較試験地） の継続調査が必要である。

今回の実生採種園における改良効果について， $\mathrm{F}_{2}$ 実生 採種園の樹高成長に有意な家系間差はなかったが（表-2）, $\mathrm{F}_{1}$ 実生採種園で樹高成長が優れていた家系ほど，その $\mathrm{F}_{2}$ 家系の樹高成長が優れていた（図-3）。この結果は，樹高 成長の劣っていた家系を $\mathrm{F}_{1}$ 実生採種園から淘汰する家系 選抜を行うことにより，さらに改良効果が高まることを示 唆している（Namkoong et al. 1988 ; 栗延 2007）。 $\mathrm{F}_{1}$ 実生 採種園の播種後 4 成長期経過時の樹高成長は，有意な家系 間差が認められたが，ブロックと家系の交互作用も有意で あった（表-1）。また， $\mathrm{F}_{2}$ 実生採種園の播種後 5 成長期経 過時の樹高成長には，有意な家系間差が認められなかった (表-2)。山田・久保田（2009）はクヌギの樹高成長におい て，初期成長の段階では有意な家系間差が認められない時 期があったことを報告している。これらのことから，クヌ ギ実生採種園で樹高成長の家系選抜を行うには，今回着目 した初期成長の段階では十分な家系間差が生じない可能性 があり，家系選抜やプロット内選抜による改良効果を得る のに最適な時期についての検討が必要であろう（Leksono et al. 2006)。また，今回設定した $\mathrm{F}_{1}$ 実生採種園と $\mathrm{F}_{2}$ 実生 採種園は少ない家系数から構成されているので，遺伝的な 多様性が低下している可能性がある。将来, $\mathrm{F}_{3}$ 実生採種 園や $\mathrm{F}_{4}$ 実生採種園等の造成による循環選抜を視野に入れ た場合，遺伝的な多様性の低下や近交係数の上昇も勘案す る必要がある（David et al. 2003）。

実生採種園では表現型によって不良木を間伐して家系選 抜や家系内選抜を行うが，家系を考慮することを除けば， 従来の森林施業で行われている定性間伐と近似した手法で ある。本研究と同様に，優良形質木から種子を採取して実 生採種園を造成し，家系選抜や家系内選抜後に自然交配種 子を採取することは，民間の苗木生産業者を含めた多くの 林業関係者が比較的容易に行うことができるであろう。こ れまでの日本のスギやヒノキを対象とした林木育種事業 は，クローン採種園による方法で行われてきているが，ク
ローン増殖が困難な樹種やその他多くの有用広葉樹では, 実生採種園による方法を採用することも有効な手段の一つ と考えられる。

今回の研究で種子を採取したクローン集植所と $\mathrm{F}_{1}$ 実生 採種園では, 結実した個体が限られていた。橋詰(1987)は, クヌギ採種林で安定的に種子生産を行うためには，疎開伐 と肥培管理を行いながら，結実の良い個体を選抜すること が重要であると指摘している。今後，実生採種園による種 子生産を実用化していくためには，家系内選抜や家系選抜 において結実の優劣を考慮するとともに, 肥培等の施業管 理や着花促進方法についても検討する必要がある。

本研究を行うにあたり, 元 森林総合研究所林木育種センター関西 育種場の栗延晋育種課長, 西村慶二育種課長, 半田孝俊育種課長, 植月充孝育種研究室長にご指導いただいた。また，同関西育種場職 員の方々には実生採種園の設定，調査，維持にご協力いただいた。 ここに記してお礼申し上げる。本研究の一部は, 日本学術振興会科 学研究費補助金（21580188）の助成を受けて行った。

\section{引用文献}

David A., Pike C, Stine R (2003) Comparison of selection methods for optimizing genetic gain and gene diversity in a red pine (Pinus resinosa Ait.) seedling seed orchard. Theor Appl Genet 107: 843849

橋詰隼人（1987）クヌギ採種林における種子生産. 広葉樹研究 4: 1-18 神戸三智雄（2005）循環選抜。（植物育種学辞典. 日本育種学会編, 培風館)。291-292

Kurinobu S (1999) Final report on seed source evaluation-Forest tree improvement project in Indonesia phase $1-$. Bull For Tree Breed Center 16: 1-46

栗延 晋（2007）林木育種のための統計解析（6）1 形質の選抜効果の 予測。林木の育種 225: 36-40

Leksono B, Kurinobu S, Ide Y (2006) Optimum age for selection based on a time trend of genetic parameters related to diameter growth in seedling seed orchards of Eucalyptus pellita in Indonesia. J For Res 11: 359-364

Leksono B, Kurinobu S, Ide Y (2008) Realized genetic gain observed in second generation seedling seed orchards of Eucalyptus pellita in Indonesia. J For Res 13: 110-116

Namkoong G, Kang HC, Brouard JS (1988) Tree breeding: Principles and strategies. Springer-Verlag

Nirsatmanto A, Leksono B, Kurinobu S, Shiraishi S (2004) Realized genetic gain observed in second-generation seedling seed orchards of Acacia mangium in South Kalimantan, Indonesia. J For Res 9: 265-269

Nirsatmanto A, Kurinobu S (2002) Trend of within-plot selection practiced in two seedling seed orchards of Acacia mangium in Indonesia. J For Res 7: 49-52

大場秀章（1989）2. クヌギ。（日本の野生植物。佐竹義輔・原寛・亘 理俊次・冨成忠夫編，平凡社)。 69-70

大庭喜八郎・勝田 柾 (1991) 林木育種学. 文永堂出版

Weng YH, Tosh K, Adam G, Fullarton MS, Norfolk C, Park YS (2008) Realized genetic gains observed in a first generation seedling seed orchard for jack pine in New Brunswick, Canada. New Forests 36: 285-298

山田浩雄・久保田正裕（2009）クヌギ精英樹自然交配家系で観察され た実現選抜効果と成長求よび台伐り効果の家系間差. 平成 20 年 版林木育種センター年報 : 73-75 